\title{
DAKWAH ISLAM DI ERA MILENIAL
}

\author{
Abdul Ghofur \\ Institut Agama Islam Syarifuddin Lumajang \\ Email : abdul.ghofur020382@gmail.com
}

\begin{abstract}
This article seeks to explain the dynamics of Islamic da'wah experienced by da'i in the face of increasingly modern times. This paper has a focus on how to preach in the millennial era by preparing preachers to be able to adapt to the development of science and technology so that they can utilize various communication and information media that are widely used by millennials.
\end{abstract}

Key words: Islamic da'wah, millennial, adaptation.

\section{PENDAHULUAN}

Di era milenial ini, ${ }^{1}$ mengajar agama Islam tidak lagi menjadi otoritas seorang ulama. Di mana saja, kapan saja dan dengan berbagai cara orang bisa belajar agama Islam. Masyarakat sekarang ini tidak hanya mengandalkan ulama sebagai sumber satu-satunya untuk mendapatkan pengetahuan keagamaan. Masyarakat bisa memanfaatkan hand phone bahkan, internet sebagai media yang begitu mudah dan praktis untuk mengetahui berbagai persoalan keagamaan, dari masalah-masalah ringan seputar ibadah sampai dengan persoalan yang pelik sekalipun, semua sangat mudah untuk diketahui dan didapatkan.

1 Millennial atau generasi millennial adalah terminologi generasi yang saat ini banyak diperbincangkan oleh banyak kalangan di dunia diberbagai bidang, apa dan siapa gerangan generasi millennial itu? Millennials (juga dikenal sebagai Generasi Millenial atau Generasi Y) adalah kelompok demografis (cohort) setelah Generasi $X$. Peneliti sosial sering mengelompokkan generasi yang lahir diantara tahun 1980 an sampai 2000 an sebagai generasi millennial. Jadi bisa dikatakan generasi millennial adalah generasi muda masa kini yang saat ini berusia dikisaran 15-34 tahun. Lancaster, L. C., \& Stillman, D. (2002). When Generations Collide: Who They Are. Why They Clash. How to Solve the Generational Puzzle at Work. New York: HarperCollins. 
Berbeda dengan era agraris, peran ulama dan tokoh agama begitu kuat dalam mempengaruhi kehidupan masyarakat. Pendapat dan sikap mereka ditiru, didengarkan dan dilaksanakan. Masyarakat rela berkorban dan mau datang ke tempat pengajian yang jaraknya jauh sekalipun, hanya karena cinta mereka kepada para ulama dan ingin mendapatkan taushiyah yang dapat dijadikan pedoman dalam menja-lani kehidupan yang baik dan benar. ${ }^{2}$

Pergeseran yang luar biasa tersebut tidak bisa dihindari dan diputar ulang seperti era agraris. Ulama dan pemerintah sekalipun tidak bisa merubah kekuatan tersebut. Modernisasi, menurut Giddens merupakan sebuah keharusan yang tidak bisa dito-lak kehadirannya. Modernisasi menjadi bagian dari perjalanan waktu dan ruang yang mesti dilalui oleh semua manusia. ${ }^{3}$

Perubahan masyarakat yang fenomenal tersebut, seharusnya diimbangi dengan adanya perubahan cara berdakwah yang dilakukan oleh para da'i. Dakwah tidak boleh jalan di tempat dan menggunakan cara-cara yang konvensional saja (ceramah). Dakwah harus dinamis, progresif, dan penuh inovasi.

Cepatnya arus informasi dan teknologi di dunia menghasilkan berbagai dinamika perkembangan keilmuan, tak terkecuali dakwah dan komunikasi Islam. Munculnya teori, konsep, dan term baru dalam keilmuan dakwah merupakan indikator serta upaya keilmuan dakwah dalam menjawab tantangan perkembangan zaman yang semakin kompleks. Namun, perkembangan keilmuan ternyata tidak selalu berbanding lurus dengan arah perbaikan dan eskalasi nilai akhlak masyarakat. ${ }^{4}$

Tulisan ini bertitik tolak dari hasil pengamatan yang penulis lakukan terhadap berbagai aktivitas dakwah yang ada di masyarakat dan sekaligus berdasarkan pada pengalaman yang penulis lakukan dalam berdakwah. Hasil pengamatan dan

${ }^{2}$ Basit, Abdul. Dakwah Cerdas di Era milenial. Jurnal Komunikasi Islam. ISBN 2088-6314. Volume 03, Nomor 01, Juni 2013.

3 Giddens, Anthony. 1990, The Consequences of Modernity, Stanford University Press, California. 39

4 Khilman Rofi Azmi. Model Dakwah Milenial untuk Homoseksual Melalui Teknik Kontinum Konseling Berbasis Alquran. Al-Balagh: Jurnal Dakwah dan Komunikasi, Vol. 4, No. 1, January - June 2019, pp. 25 - 58, DOI: 10.22515/balagh.v4i1.1557 ISSN: 2527-5704 (P) ISSN: 2527-5682 (E) 
pengalaman tersebut kemudian dianalisis dengan menggunakan teori-teori dakwah dan komu nikasi. 


\section{PEMBAHASAN}

Salah satu ciri abad ini adalah meluasnya penggunaan media massa. dan tren ini di masa mendatang akan terus memperlihatkan akselerasinya yang susah untuk diikuti jejaknya. Sekarang ini, dengan bantuan teknologi komunikasi yang serba mutakhir, sebuah pesan dapat mencapai miliaran manusia sekaligus di mana pun mereka berada. ${ }^{5}$

Perkembangan teknologi yang serba canggih ini adalah sebuah peluang besar para kader dan juru dakwah untuk terus memikirkan cara berdakwah. Tiada lain sebuah ijtihad dalam mencari peluang-peluang pesan dakwah yang bisa disalurkan ke berbagai media. Seperti yang sudah terlihat dilakukan oleh para penggiat bisnis dengan terus melakukan inovasi produknya ke berbagai media yang bisa menjangkau luas masyarakat konsumennya.

Ikhtiar ini sudah pernah dilakukan oleh Al-Ghazali ketika waktu itu beliau memikirkan cara berdakwah dalam majelis ilmu. Dan sudah seperti itu pula hendaknya para dai memikirkan kemungkinan dakwah melalui media massa. selain itu, Al-Ghazali juga pernah merenungkan pengaruh buku-buku filsafat Yunani pada pemikiran Islam, sedalam itu pula hendaknya para dai masa kini merenungkan pengaruh infiltrasi kebudayaan melalui media massa. ${ }^{6}$

Betapa hebatnya media mengubah tatanan kehidupan masyarakat dengan mudah dan cepat. Tidak sedikit masyarakat yang tadinya tidak melek sekarang menjadi melek terhadap informasi yang begitu banjir di belantara media. Melihat peluang seperti itu, dakwah pun sangat bisa dilakukan di berbagai media massa. Namun para pembuat pesannya inilah yang harus berubah seiring dengan

\footnotetext{
${ }^{5}$ Encep Dulwahab. Dakwah di Era Konvergensi Media. Jurnal Ilmu Dakwah Vol. 5 No. 16 JuliDesember 2010.

${ }^{6}$ Jalaluddin Rakhmat, Hegemoni Budaya, (Yogyakarta: Bentang. 1997), hlm. 50.
} 
perkembangan teknologi komunikasi yang terus berakselerasi memenuhi kebutuhan manusia. $^{7}$

Kini, masyarakat tidak hanya melek terhadap pentingnya dan signifikannya media terhadap diri dan lingkungannya. Lebih dari itu, masyarakat kini tengah gandrung dengan internet. Tak ubahnya seperti sebuah mainan, internet sudah dianggap mainan yang mengasyikan masyarakat. Di mana internet menjadi telah menjadi teman pengganti di waktu-waktu senggangnya.

1. Paradigma Dakwah era Milenial

Dinamisasi kehidupan modern yang semakin tinggi dan sangat kompetitif telah banyak mempengaruhi umat manusia senantiasa memandang persoalan hidup secara pragmatis, logis, serba instan dan bahkan metematis. Keadaan yang demikian ini di samping membawa manfaat berupa kemajuan ilmu pengetahuan dan teknologi yang semakin memudahkan aktifitas manusia, juga telah membawa implikasi negatif berupa lemahnya semangat transendental dan memudarnya hubungan sosial. Implikasi tersebut berlangsung demikian lama, sehingga dewasa ini telah melahirkan berbagai kenyataan sosial yang cukup bertentangan dengan cita-cita. ${ }^{8}$

Untuk mengatasi dinamisasi kehidupan yang semakin kompleks tersebut maka dibutuhkan Paradigma baru dalam mengusung dakwah Islam yang mempertimbangkan jenis dan kualitas permasalahan yang dihadapi oleh umat dewasa ini. Di sinilah institusi dakwah secara keteraturan dituntut untuk dapat melakukan usaha-usaha dakwah secara sistematis dan professional melalui langkah strategis, sebagaimana yang sudah diterangkan dalam firman Allah, “Dan katakanlah, Bekerjalah kamu maka Allah.

Dalam Annual International Conference on Islamic Studies (AICIS) yang diselenggarakan di Surabaya pada tanggal 5-8 November 2012, keberadaan keilmuan dakwah dipertanyakan.Quo Vadis keilmuan dan pendidikan yang ada di

7 Encep Dulwahab. Dakwah di Era Konvergensi Media. Jurnal Ilmu Dakwah Vol. 5 No. 16 JuliDesember 2010.

${ }^{8}$ Istina Rakhmawati. Paradigma Dakwah Upaya Merespon Problematika Umat Islam di Era Modern. AT-TABSYIR: Jurnal Komunikasi Penyiaran Islam 
Fakultas atau Jurusan Dakwah? Pertanyaan tersebut memang bukan sesuatu yang baru. Sebelum mendapatkan pengakuan dari Lembaga Ilmu Pengetahuan. ${ }^{9}$

Indonesia (LIPI), pertanyaan tersebut telah mencuat ke permukaan dan menjadi agenda besar di Fakultas atau Jurusan Dakwah. Namun, pertanyaan yang ada dalam AICIS kali ini dapat menjadi bahan evaluasi dan urgen untuk dikemukakan kembali. Mengingat perkembangan keilmuan dakwah dari semenjak pengakuan LIPI (1982) hingga sekarang belum mengalami perkembangan yang signifikan. Keilmuan dakwah belum mampu memberikan landasan filosofi terhadap pesatnya perkembangan aktivitas dakwah di masyarakat.

Implikasinya, aktivitas dakwah tidak bisa dikendalikan dan dievaluasi efektivitasnya. Dakwah bisa jadi menjurus kepada kekerasan, konflik dan menyesatkan masyarakat. Selain itu, keilmuan dakwah juga belum mampu menyiapkan lulusan dari Fakultas atau Jurusan dakwah yang dapat berkiprah dan mendapat pengakuan dari masyarakat.

Dakwah perlu dilakukan rebranding dengan cara membangun landasan filosofis dari keilmuan dakwah dan memperkuat peran organisasi dakwah secara profesional. ${ }^{10}$ Perlunya brand baru disebabkan karena term dakwah dikenal di masyarakat sebagai term normatif, kurang compatible dengan era modern dan cenderung bersifat keakhiratan. Kalaupun dikenal, dakwah identik dengan ceramah atau tabligh.

Begitu pun pada masyarakat Barat, pemaknaan dakwah diterjemahkan sebagai kegiatan missionaris dan propaganda.. Dakwah secara akademik tidak banyak diketahui oleh masyarakat, padahal jum- lah Fakultas atau Jurusan

\footnotetext{
${ }^{9}$ Basit, Abdul. Dakwah Cerdas di Era milenial. Jurnal Komunikasi Islam. ISBN 2088-6314. Volume 03, Nomor 01, Juni 2013.

${ }^{10}$ Aziz, Moh. Ali. 2012, A Roadmap for Rebranding Da'wah, makalah dipresentasikan pada AICIS, Surabaya, 5-8 November.

${ }^{11}$ Poston, Larry. 1992, Islamic Da'wah in the West, Oxford University Press, New York. 3.
} 
Dakwah di Perguruan Tinggi Agama Islam di Indonesia kurang lebih ada 53 Fakultas/Jurusan Dakwah. ${ }^{12}$

${ }^{12}$ Basit, Abdul. Dakwah Cerdas di Era milenial. Jurnal Komunikasi Islam. ISBN 2088-6314. Volume 03, Nomor 01, Juni 2013. 
2. Da'i dan Teknologi Informasi

Untuk mendukung adanya perubahan dalam berdakwah, para da'i perlu terus meningkatkan wawasan, ilmu dan kemampuan dalam melakukan dakwah. Da'i tidak merasa puas dengan ilmu yang dimilikinya, melainkan terus belajar (long life education). Apalagi pada era milenial seperti sekarang, kemampuan da'i dalam mengoperasikan internet merupakan prasyarat yang tidak bisa ditawartawar. ${ }^{13}$ Dengan teknologida'i bisa menulis dan menyimpan gagasan-gagasan yang akan disampaikan kepada masyarakat. ${ }^{14}$

Pada era milenial, ilmu yang berkembang bersifat multidisipliner dan komplementer. Ilmu agama yang selama ini menjadi pegangan da'i sebagai sumber utama perlu diperkuat dengan keilmuan lainnya agar apa yang disampaikan ke masyarakat menjadi kokoh dan dapat dioperasionalkan di lapangan. Ilmu agama Islam dapat diperkuat dengan menggunakan kajian ilmu psikologi, sosiologi, sejarah dan sebagainya.

Sebagaimana fatwa Syekh Adil al-Kalbani, yang melawan arus pendapat umum di kalangan ulama Saudi. Al-Kalbani, yang semula membela pendapat yang mengharamkan musik dan nyanyian tiba-tiba berubah pikiran dan menganggap bermain musik dan menyanyi tidaklah bertentangan dengan ajaran Islam. Fatwa ini mendapat kritik keras dari kalangan ulama yang menganggap bermusik dan bernyanyi diharamkan oleh syariat Islam. ${ }^{15}$ Jika fatwa tersebut hanya berpedoman pada sumber agama saja tanpa memperhatikan kajian sosiologi masyarakat, maka fatwa tersebut akan bertabrakan dengan realitas yang berkembangan di masyarakat bahwa musik merupakan kebutuhan masyarakat dan bahkan menjadi industri kreatif yang bisa mensejahterakan.

\footnotetext{
${ }^{13}$ Belajar komputer dan internet bukanlah perkara yang sulit bagi para da'i, jauh lebih sulit belajar bahasa Arab atau bahasa Jawa. Satu sampai tiga hari, dijamin bisa manakala ada kemauan kuat untuk belajar. Prinsipnya jangan takut salah, komputer tidak akan rusak atau terbakar, dan jangan malu bertanya.

${ }^{14}$ Basit, Abdul. Dakwah Cerdas di Era milenial. Jurnal Komunikasi Islam. ISBN 2088-6314. Volume 03, Nomor 01, Juni 2013.

${ }^{15}$ Effendi, Djohan, Islam di Antara Teks dan konteks, makalah disampaikan dalam (ACIS) ke-10, Banjarmasin, 1-3 Nopember. 6.
} 
Dengan memperluas pendekatan dalam mengembangkan ilmu agama Islam, maka kegiatan dakwah pun bisa diperluas dengan berbagai pendekatan. Kegiatan dakwah diturunkan dari keilmuan dakwah yang notabenemenjadi bagian dari keilmuan agama Islam. Kegiatan ini bisa didekati dengan Ilmu Manajemen, Politik, Sosiologi, Antropologi, Ilmu Kesehatan, Psikologi dan sebagainya. Dengan cara demikian, kegiatan dakwah amat variatif.

Da'i perlu melebur dan turun secara bersama-sama dalam memecahkan problematika yang dihadapi oleh masyarakat. Da'i tidak hanya bersikap No Action Talking Only dan hanya sebagai narasumber, melainkan juga sebagai motivator, manajer, fasilitatordan inisiator. Masyarakat kesulitan dalam memecahkan masalahnya karena minimnya masyarakat yang menjadi penggerak perubahan.

Tidak banyak pemimpin Islam yang memiliki kepedulian pada masyarakat yang mustad'afin. Ajaran Islam juga mendorong umatnya untuk peduli pada kaum mustad'afin. ${ }^{16}$ Pada konteks inilah, da'i perlu mengambil peran sebagai pemimpin yang dapat melakukan perubahan pada masyarakat sebagaimana firman Allah dalam da'wah bil-qaul dan da'wah bil-‘amal. Allah berfimran yang artinya:

"... siapakah yang lebih baik perkataannya daripada orang yang menyeru kepada Allah, mengerjakan amal yang saleh, dan berkata: "Sesungguhnya aku Termasuk orang-orang yang menyerah diri?"(QS. 41: 33).

Dalam memberdayakan masyarakat, da'i dapat merubah ideologi yang selama ini menjadi pesan dakwah menuju ideologi kemakmuran dan kesejahteraan atau dari materi yang bersifat teologis menuju materi yang bersifat sosiologis. Dengan membawa masyarakat untuk bekerja keras, mengenal dunia, disiplin waktu, memanfaatkan alam, menjaga lingkungan yang bersih, saling berbagi dan lain-lain.

Untuk mendukung da'i dalam memberdayakan masyarakat, da'i bisa mengembangkan beberapa fasilitas hukum yang diperkenalkan Allah swt seperti

\footnotetext{
${ }^{16}$ Sepuluh surat awal (al-Lahab, al-Ma'un, al-Humajah, al-Dhuha dan sebagainya) yang diturunkan oleh Allah swt mengecam pada umat yang tidak memedulikan sesama dan orang-orang yang lemah.
} 
zakat, infaq, shadaqah dan wakaf. Fasilitas inilah yang bisa dijadikan modal utama dalam pemberdayaan masyarakat. Kekayaan di masyarakat Indonesia pada dasarnya tinggi. Hal penting yang diperlukan adalah bagaimana memberikan pemahaman dan kepercayaan kepada masyarakat bahwa dana mereka dapat disalurkan pada jalan yang benar.

Dhompet Dhuafa merupakan salah satu Lembaga ZISWAF yang sukses memanfaatkan dana umat untuk kesejahteraan masyarakat luas. Lembaga tersebut memiliki lembaga pendidikan untuk orang miskin setiap kalangan, lembaga kesehatan cuma-cuma, bimbingan rohani bagi pasien, membantu tindakan darurat bagi masyarakat yang terkena musibah, membantu para pedagang dan sebagainya.

Penulis meyakini, setiap insan sebenarnya memiliki kemampuan untuk bisa mengelola dana umat manakala kita memiliki kemampuan manajerial yang profesional dan dipercaya umat. Tunjukkan kepada masyarakat bahwa kita memiliki kemampuan dan dapat dipercaya oleh masyarakat. Gagasan besar apapun tanpa ada tindakan nyata sulit untuk direalisasikan. Oleh karena itu, da'i perlu terjun langsung menggerakkan masyarakat dengan menciptakan berbagai model gerakan dakwah yang bisa membawa kesejahteraan bagi masyarakat dan dapat memberi warna baru pada genereasi milenial. ${ }^{17}$

3. Konvergensi Media Dakwah

Fenomena yang sering disebut sebagai konvergensi media ini memunculkan beberapa kemajuan penting. Di ranah praktis, konvergensi media tidak saja memperkaya informasi yang disajikan, namun juga memberi berbagai alternatif pilihan kepada khalayak untuk memilih informasi yang sesuai dengan seleranya.

Konvergensi media memberikan kesempatan baru dalam penanganan, penyediaan, distribusi dan pemrosesan seluruh informasi, baik yang bersifat visual, audio, data dan sebagainya. Salah satu bentuk kebermanfaatan dari

${ }^{17}$ Basit, Abdul. Dakwah Cerdas di Era milenial. Jurnal Komunikasi Islam. ISBN 2088-6314. Volume 03, Nomor 01, Juni 2013. 
munculnya era korvergensi media ini adalah jurnalisme online. Fenomena jurnalisme online yang dimanfaatkan oleh media massa dalam menyajikan materi informasinya dalam bentuk on line sekarang ini, merupakan contoh menarik. Di mana, khalayak selaku pengakses media alias pembaca, tinggal meng-click informasi yang diinginkan di internet, dalam waktu sekejap ribuan informasi yang dicari pun akan mudah didapatkan. ${ }^{18}$

Aplikasi teknologi komunikasi terbukti mampu mem-by pass jalur transportasi pengiriman informasi media kepada khalayaknya. Di sisi lain, jurnalisme online juga memampukan para pemilik media untuk terus-menerus meng-up date informasi yang mereka tampilkan, seiring dengan adanya informasi-informasi baru di lapangan. ${ }^{19}$

Kemudian secara teoritik, dengan munculnya media konvergen, maka sejumlah pengertian mendasar tentang komunikasi massa tradisional perlu diperdebatkan kembali. Karena konvergensi menimbulkan perubahan signifikan dalam ciri-ciri komunikasi massa tradisional atau konvensional. Media konvergen memadukan komunikasi massa dan komunikasi antarpribadi dalam satu media sekaligus.

Karenanya, terjadi apa yang disebut sebagai demasivikasi (demassification), yakni kondisi di mana ciri utama media massa yang menyebarkan informasi secara masif menjadi lenyap. Arus informasi yang berlangsung pun menjadi makin personal, karena tiap orang mempunyai kebebasan untuk memilih informasi yang mereka butuhkan. ${ }^{20}$

Teknologi komunikasi baru memungkinkan sebuah media memfasilitasi komunikasi interpersonal yang termediasi. ${ }^{21}$ Dahulu ketika internet muncul di penghujung abad ke21, pengguna internet dan masyarakat luas masih

${ }^{18}$ Encep Dulwahab. Dakwah di Era Konvergensi Media. Jurnal Ilmu Dakwah Vol. 5 No. 16 JuliDesember 2010.

${ }^{19}$ Anang Hermawan, Tantangan Masa Depan Konvergensi Media, BERNAS JOGJA edisi Kamis, 5 April 2007.

${ }^{20} \mathrm{Ibid}$

${ }^{21}$ Encep Dulwahab. Dakwah di Era Konvergensi Media. Jurnal Ilmu Dakwah Vol. 5 No. 16 JuliDesember 2010. 
mengidentikkannya sebagai alat semata. Berbeda halnya sekarang, internet menjadi media tersendiri yang bahkan mempunyai kemampuan interaktif.

Dalam konteks yang lebih luas, konvergensi media sesungguhnya bukan saja memperlihatkan perkembangan teknologi yang cepat. Konvergensi media telah berperan besar dalam mengubah hubungan antara teknologi dengan industri. Lebih jauhnya lagi, konvergensi media telah menuntun gaya hidup menjadi lebih praktis dan serba instan. Harus diakui, kemajuan atau lahirnya konvergensi media ini telah mematikan aktivitas lainnya, yaitu media-media yang sudah lahir sebelumnya. Di negara maju semacam Amerika, terdapat tren menurunnya pelanggan media cetak dan naiknya pelanggan internet.

Bahkan diramalkan dalam beberapa dekade mendatang, di negara tersebut, masyarakatnya akan meninggalkan media massa tradisional dan beralih ke media konvergen. Tren ini tidak hanya terjadi di negara Paman Sam, tetapi geliatnya terus merebak ke berbagai negara di belahan dunia lainnya. Fenomena ini, bukan tidak mungkin suatu saat nanti, peran jurnalisme online akan menggantikan peran pers konvensional. Karena nilai plus dari konvergensi media adalah bisa memberikan kesempatan baru kepada publik, untuk memperluas pilihan akses medianya sesuai dengan selera mereka, yang itu tidak didapatkan di media-media lainnya. ${ }^{22}$

Memang ada kekhawatiran dari munculnya konvergensi media ini. Namun jika isinya betul-betul terjaga, terlebih lagi ada muatan dakwah yang pesannya sudah terbentuk dengan rapih, minimal kekhawatiran akan efek negatif dari konvergensi media ini tidak akan ada lagi. Bahkan sebagian kalangan merasa aman, pasalnya bahwa isi konvergensi media yang berorientasi dakwah, pada bagian tertentu akan mengamankan moral generasi muda, dan ini merupakan salah satu poin penting yang harus dipikirkan para dai terhadap perkembangan dunia konvergensi media.

22 Encep Dulwahab. Dakwah di Era Konvergensi Media. Jurnal Ilmu Dakwah Vol. 5 No. 16 JuliDesember 2010. 


\section{PENUTUP}

Fenomena globalisasi yang paling penting untuk disorot adalah penyebaran cara pandang seputar hubungan keluarga, kerukunan umat, sosial, terutama yang berkembang di negara maju yang notabene merupakan pemeran utama globalisasi. Dakwah di era milenial ini dapat dilakukan dengan memposisikan dakwah sebagai ilmu yang dapat dikembangkan dan dievaluasi keberadaannya. Keilmuan dakwah perlu dikembangkan menjadi ilmu komunikasi Islam yang lebih compatible dengan perkembangan masyarakat dan ilmu pengetahuan di era milenial ini. Selain itu, kemampuan da'i dalam menciptakan dan memanfaatkan teknologi informasi sebagai media dakwah perlu terus menerus diupayakan agar dakwah betul-betul dapat dirasakan manfaatnya oleh masyarakat. Prinsip “khair al-nas anfa'uhum li al-nas" dapat dijadikan landasan oleh para da'i dalam menggerakkan kegiatan dakwah di masyarakat.

\section{REFERENSI}

Azmi, Khilman Rofi. Model Dakwah Milenial untuk Homoseksual Melalui Teknik Kontinum Konseling Berbasis Alquran. Al-Balagh: Jurnal Dakwah dan Komunikasi, Vol. 4, No. 1, January - June 2019, pp. 25 - 58, DOI: 10.22515/balagh.v4i1.1557 ISSN: 2527-5704 (P) ISSN: 2527-5682 (E)

Aziz, M. Ali. 2012, A Roadmap for Rebranding Da'wah, makalah dipresentasikan pada AICIS, Surabaya, 5-8 November.

Baidhawy, Zakiyudin. 2010, Dinamika Radikalisme dan Konflik Bersentimen Keagamaan di Surakarta, makalah dipresentasikan pada ACIS ke-10, Banjarmasin 1- 4 November.

Bakti, A. Faisal. 2009, Applied Communication to Dakwah for Peace, makalah dipresentasikan pada Kuliah Umum di Pascasarjana UIN Alauddin Makasar 1 September. 
Basit, Abdul. Dakwah Cerdas di Era milenial. Jurnal Komunikasi Islam. ISBN 2088-6314. Volume 03, Nomor 01, Juni 2013.

Bungin, Burhan. 2008, Sosiologi Komunikasi, Kencana, Jakarta.

Effendi, Djohan, Islam di Antara Teks dan konteks, makalah disampaikan dalam (ACIS) ke-10, Banjarmasin, 1-3 Nopember.

Giddens, Anthony. 1990, The Consequences of Modernity, Stanford University Press, California.

Istina Rakhmawati. Paradigma Dakwah Upaya Merespon Problematika Umat Islam di Era Modern. AT-TABSYIR: Jurnal Komunikasi Penyiaran Islam

Jeffres, Leo W.1986, Mass Media Process and Effects, Waveland Press, Illinois.

Mowlana, Hamid.1996, Global Communication in Transition the End of Diversity? Sage Publications, London.

Poston, Larry. 1992, Islamic Da'wah in the West, Oxford University Press, New York.

Tasmara, Toto 1997, Komunikasi Dakwah, Gaya Media Pratama, Jakarta. 